This item was submitted to Loughborough's Research Repository by the author.

Items in Figshare are protected by copyright, with all rights reserved, unless otherwise indicated.

\title{
Above- and below-ground competition effects of two heathland species: implications for growth and response to herbivory in birch saplings
}

PLEASE CITE THE PUBLISHED VERSION

http://dx.doi.org/10.1016/j.baae.2006.08.005

PUBLISHER

(C) Elsevier

VERSION

SMUR (Submitted Manuscript Under Review)

\section{LICENCE}

CC BY-NC-ND 4.0

\section{REPOSITORY RECORD}

Millett, Jonathan, A.J. Hester, P. Millard, and A.J.S. McDonald. 2019. "Above- and Below-ground Competition Effects of Two Heathland Species: Implications for Growth and Response to Herbivory in Birch Saplings". figshare. https://hdl.handle.net/2134/13428. 
This item was submitted to Loughborough's Institutional Repository (https://dspace.lboro.ac.uk/) by the author and is made available under the following Creative Commons Licence conditions.

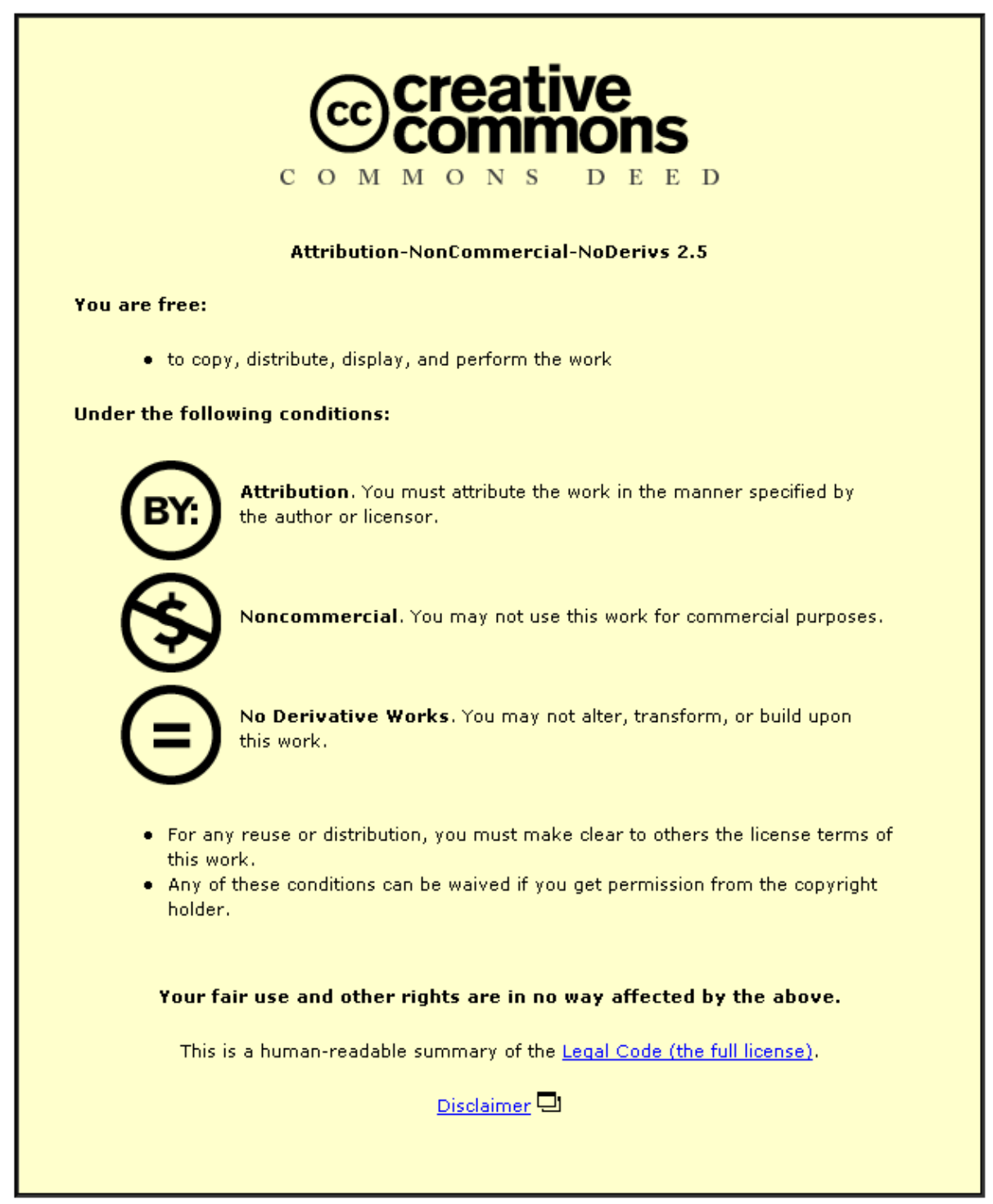

For the full text of this licence, please go to: http://creativecommons.org/licenses/by-nc-nd/2.5/ 


\section{Above- and below-ground competition effects of two heathland species: implications for growth and response to herbivory in birch saplings.}

J. Millett $^{1,2, *}$, A.J. Hester ${ }^{1}$, P. Millard ${ }^{1}$ and A.J.S. McDonald ${ }^{2}$

${ }^{1}$ The Macaulay Institute, Craigiebuckler, Aberdeen, AB15 8QH

${ }^{2}$ Department of Plant and Soil Sciences, School of Biological Sciences, Aberdeen

University, Aberdeen

* Current address: Deanery of Sciences and Social Science, Liverpool Hope

University College, Hope Park, Liverpool, L16 9JD

*Corresponding Author. E-mail: milletj@hope.ac.uk; phone: (+44) (0)151 2912174

Running headline: Response of birch to competition and herbivory

Number of words:

Altogether: 4318

Title: 19

Abstract: 307 


\section{Summary}

We examined experimentally the effect of competition from two common heathland plant species (Calluna vulgaris or Molinia caerulea) on Betula pubescens saplings subjected to simulated mammalian browsing damage. We tested two hypotheses: that B. pubescens saplings alter their growth allocation in response to different patterns of competition from the two species in order to maximise resource acquisition; and that, when only $B$. pubescens saplings are damaged, herbivory reduces its ability to compete with both species.

In an ex-situ experiment we grew B. pubescens saplings in the presence of below- or above- and below-ground interactions from C. vulgaris or M. caerulea. Saplings were also subjected to simulated browsing by clipping (50\% of current year's growth), either pre-senescence or at bud-burst. We measured the morphology and dry mass allocation response of the saplings over a period of two years.

We found that competition reduced sapling dry mass by approximately $50 \%$, but $C$. vulgaris reduced dry mass to a greater extent than did $M$. caerulea. The total competition intensity of $C$. vulgaris was greater than that of $M$. caerulea, due to an apparent facilitative effect of $M$. caerulea shoots on birch growth. Saplings compensated for browsing damage, resulting in no difference in dry mass one year after damage. However, sapling morphological responses to browsing damage were dependent on the competing species.

Despite the large competitive effect of below-ground interactions, saplings did not increase allocation to root growth as predicted. Additionally, in response to aboveground interactions from M. caeruela, saplings increased allocation to root growth. 
This study highlights the importance of patterns, as well as intensity, of competition in determining plant responses to inter-specific interactions. Sapling responses did not follow the pattern predicted by the balanced-growth hypothesis. We suggest that this is due to the multi-functionality of plant component parts and the balance between competitive and facilitative effects of interacting plants.

\section{Key words:}

Betula pubescens, facilitation, herbivory, plant interactions, tree saplings.

\section{Introduction}

Understanding plant interactions is fundamental to understanding plant community dynamics (Grime 1973; Grime 1979, Tilman 1988; Grace \& Tilman 1990). Interactions between plants can have positive (facilitative) and/or negative (competitive) effects (Callaway \& Walker 1997; Holzapfel \& Mahall 1999) on plant growth. Additionally, competition can alter patterns of growth allocation and morphology due to competitor effects on the relative availability of different resources. This facilitates optimal resource acquisition (e.g. Farrar 1999, Müller, Schmidt \& Weiner 2000). In response to shoot competition plants are predicted to increase shoot/leaf growth to out-compete neighbours (Reynolds \& Antonio 1996). Alternatively, in response to root competition plants are predicted to increase allocation to root growth to compensate for the competition-induced reduction in nutrient provisioning (e.g. Wilson \& Tilman 1995). The separation of above- and below-ground components of plant interactions provides a method of testing plant responses to each component in isolation. The general consensus in the literature is that competition below-ground tends to be more important than competition aboveground (Wilson 1988). However, the relative contribution of each competition 
component is very variable, is strongly influenced by environmental factors (Wilson \& Tilman 1991; Twolan-Strutt \& Keddy 1996) and may be site and/or species specific.

Browsing from large herbivores also restricts tree sapling survival and growth in many systems across the world (Bergström \& Danell 1987; Hester, Mitchell \& Kirby 1996; Van Hees, Kuiters \& Slim 1996; Millard, Hester, Wendler \& Baillie 2001; Hester, Millard, Baillie \& Wendler 2004) and, in some areas, prevents the establishment, expansion or renewal of woodland (Hester, Edenius, Buttenschon \& Kuiters 2000; Kuiters \& Slim 2002; Hester, Bergman, Iason \& Moean (in press)). Herbivory can alter associations between plants (Louda, Keeler \& Holt 1990; Crawley 2000) by reducing their ability to compete (Harper 1977; Reader 1992). Additionally, browsing mammals are selective, exhibiting a preference for one species over another (Danell \& Bergström 2002). This asymmetric herbivory often increases the effect of competition on the damaged plant (Conell 190). Furthermore, browsing induced alterations in plant morphology and root:shoot ratios can also impact on the ability of the plant to compete (Huntley 1991).

Interactions between competition and herbivory are predicted to be additive (i.e. the relative effect of one is the same, regardless of the effect of the other). However, the studies that are available have found large variations in the interactions between herbivory and competition (e.g Reader 1992; Bonser \& Reader 1995; Dormann, Van der Wal \& Bakker 2000). The effects appear to be highly species-specific and also depend on the competing species. For example, Millett, Hester, Millard \& McDonald (in press) found that high levels of herbivory by red deer removed any difference in the effect of Calluna vulgaris (L.) Hull or Molinia caerulea (L.) Moench on Betula 
pubescens Ehrh. sapling growth. Hjältén (2001) also found that the ability of $B$. pubescens to compensate for herbivory was reduced by increased intra-specific competition. However, Meiners and Handel (2000) found that herbivory did not influence the effect of competition from herbaceous vegetation on tree sapling growth. There is clearly a need for further research to better understand how competition and herbivory interact and to identify the mechanisms driving such interactions.

Competition between tree seedlings and grasses/shrubs strongly influences tree establishment (Holl 1998). In the ex-situ enclosure study reported here, we measured above-ground, below-ground and total competition intensity between two heathland plants with contrasting growth patterns (C. vulgaris and $M$. caerulea) and $B$. pubescens saplings, and recorded the effect of simulated browsing on these interactions. Betula pubescens is a deciduous tree and is widely distributed in Europe, as a dominant or co-occurring component of many semi-natural forest systems (Atkinson 1992). M. caerulea and C. vulgaris are both widespread across Northern Europe, and are dominant in many of the upland areas where birch regeneration is widespread. The two species have contrasting growth habits; C. vulgaris is an evergreen ericaceous shrub whereas $M$. caerulea is a deciduous tussock-grass (Gimingham 1960; Taylor, Rowland \& Jones 2001). The aim of this study was to identify the relative above- and below-ground interaction effects of the two species, and the influence of browsing damage on sapling responses to these effects. Specifically, we tested the following hypotheses: 1. That B. pubescens saplings increase allocation of growth to roots due to the reduction in nutrient availability as a result of below-ground competition, and allocation to above-ground plant parts is increased by above-ground interactions due to the reduction in above-ground resource 
availability; and 2. That when only the tree saplings are damaged, browsing increases the intensity of competition due to a reduction in the fitness of the sapling.

\section{Materials and methods}

\section{Experimental design and set-up}

180 2-year-old B. pubescens seedlings (Forestry Commission seed: UK provenance region 202 - NE Scotland) were transplanted from a nursery when dormant and planted in sterile sand in pots (300 mm diameter x $260 \mathrm{~mm}$ deep) in early spring 2002. To ensure adequate drainage, the pots were filled with $50 \mathrm{~mm}$ of gravel $(8 / 16)$, $50 \mathrm{~mm}$ of coarse sand and then fine white sand (number 60) to the top.

The pots were placed in a covered, fenced enclosure at the Macaulay Institute in Aberdeen, Scotland $\left(57^{\circ} \mathrm{N}, 2^{\circ} \mathrm{W}\right)$. All pots were watered with a complete nutrient solution containing $3 \mathrm{mM} \mathrm{NH}_{4}{ }^{+} \mathrm{NO}_{3}{ }^{-}$and other nutrients, as described by Millard and Proe (1991). In 2002 each pot received $300 \mathrm{~cm}^{3}$ of nutrient solution two times a week; in 2003 and 2004 this was increased to $500 \mathrm{~cm}^{3}$ to reflect the increasing size of plants during the growing season March-October (and therefore nutrient requirements). The pots were also watered with demineralised water to avoid excessive drying. Pots were moved into a glasshouse over winter, and kept frost-free.

At the start of the first growing season, all saplings were clipped to $100 \mathrm{~mm}$ height, which removed most 2001 growth, leaving a single stem of primarily old growth with a number of lateral buds. The aim of this was two-fold: to start the experiment with all saplings heavily 'browsed' and to 'standardise' their initial height to that of the surrounding vegetation.

Two competing species treatments (M. caerulea or C. vulgaris) were crossed with two levels of competition location (above- and below-ground or below-ground only). 
These competition treatments, in addition to a control with no competing plants resulted in a total of five competition treatments. In addition, three browsing treatments were applied to the saplings (detailed below). The competition and browsing treatments were combined in a $5 \times 3$ factorial design, giving 15 treatment combinations. The pots were arranged in a randomized design in 12 blocks, giving 6 replicates of each treatment combination, to be harvested at two time points (late summer 2003 and spring 2004).

\section{Competition treatments}

Competition intensity was measured by growing saplings with competition from either M. caerulea or C. vulgaris. Two-year-old C. vulgaris plants were purchased from a nursery (UK provenance zone 109 - SE Scotland). Rhizomes of dormant $M$. caerulea plants were collected from the field in Aberdeenshire $\left(57^{\circ} \mathrm{N}, 2^{\circ} \mathrm{W}\right)$, Scotland in early March 2002. Six 'plugs' of C. vulgaris or six groups of three $M$. caerulea rhizomes (to give similar sized plant groups) were planted in a circle at equal spacing around the $B$. pubescens saplings and $80 \mathrm{~mm}$ from the saplings.

Competition was controlled as follows (Fig. 1): No neighbours (NN, Fig. 1a) saplings were grown in the pots with no competing vegetation; Neighbour roots and shoots (NRS, Fig. 1b) - the competing plants were allowed to fully interact with the saplings; Neighbour roots (NR, Fig. 1c) - a wire mesh cone (height $150 \mathrm{~mm}$, base diameter $50 \mathrm{~mm}$, top diameter $150 \mathrm{~mm}$ ) was placed around the base of the sapling. The surrounding plants were trained around this cone as they grew to maintain the above-ground competition removal treatment. It was assumed that training the shoots of the surrounding plants behind the mesh cone did not significantly affect the root growth of the plants. Therefore, above-ground interactions were effectively 
eliminated without altering the below-ground interactions. This design is equivalent to the 'target' technique described by McPhee \& Aarssen (2001).

\section{Browsing treatments}

The B. pubescens saplings were subjected to one of three simulated browsing treatments. These were: no browsing (control); late summer browsing (August 2002 at first sign of leaf senescence); or browsing at bud-burst (March 2003). The simulated browsing treatment was applied by clipping off half of the current year's shoots from each sapling. The entire shoot was removed, starting with the leader and then cutting every alternate shoot (as in Hester et al. 2004).

\section{Measurements and harvesting}

Saplings were measured at planting (longest root length, height, fresh mass, number of buds and stem diameter), and at harvest (height, canopy cover, number of leaves, number of short shoots, terminal long shoots, lateral long shoots, stem diameter, number of branches). The blocks were randomly allocated to one of two groups for harvesting. Plants in group 1 were destructively harvested on $8^{\text {th }}$ September 2003 (pre-senescence 2003), and plants in group 2 were harvested 64 days after bud-burst in 2004. Each sapling was separated into leaves, roots, old shoots (previous years' growth) and new shoots (current year's growth). Abscised leaves were collected from the saplings in group 2 in autumn 2003 by placing netting around each sapling. All plant material was freeze-dried and weighed. 


\section{Data analysis}

\section{Competition intensity}

For each block, total sapling biomass was used to calculate competition intensity and its two components. We calculated relative competition intensity (RCI) as follows (after Reader, Wilson, Belcher, Wisheu, Keddy et al. 1994):

total competition intensity $\mathrm{RCI}_{\mathrm{T}}=\left(\mathrm{S}_{\mathrm{NN}}-\mathrm{S}_{\mathrm{NRS}}\right) / \mathrm{S}_{\mathrm{NN}}$,

root competition intensity $\mathrm{RCI}_{\mathrm{R}}=\left(\mathrm{S}_{\mathrm{NN}}-\mathrm{S}_{\mathrm{NR}}\right) / \mathrm{S}_{\mathrm{NN}}$,

shoot competition intensity $\quad \mathrm{RCI}_{\mathrm{S}}=\left(\mathrm{S}_{\mathrm{NR}}-\mathrm{S}_{\mathrm{NRS}}\right) / \mathrm{S}_{\mathrm{NN}}=\mathrm{CI}_{\mathrm{T}}-\mathrm{CI}_{\mathrm{R}}$

Absolute competition intensity (ACI) was calculated as follows (after Wilson \& Keddy 1986):

total competition intensity $\quad \mathrm{ACI}_{\mathrm{T}}=\mathrm{S}_{\mathrm{NN}}-\mathrm{S}_{\mathrm{NRS}}$,

root competition intensity $\quad \mathrm{ACI}_{\mathrm{R}}=\mathrm{S}_{\mathrm{NN}}-\mathrm{S}_{\mathrm{NR}}$,

shoot competition intensity $\quad \mathrm{ACI}_{\mathrm{S}}=\mathrm{S}_{\mathrm{NR}}-\mathrm{S}_{\mathrm{NRS}}=\mathrm{CI}_{\mathrm{T}}-\mathrm{CI}_{\mathrm{R}}$

Where $S_{N N}, S_{N R}$ and $S_{N R S}$ are the dry weights of the saplings with no neighbours, neighbour roots and neighbour roots and shoots treatments respectively. The CI was calculated separately for each competing species, to give two values per block. The calculation of CI yields an index where competitive (i.e. negative) interactions result in positive values and facilitative (i.e. positive) interactions result in negative values. The two measures of competition intensity may yield different results (Campbell \& Grime 1992; Grace 1995, Wiegelt \& Jolliffe 2003). Therefore, both were calculated and presented for discussion.

\section{Calculation of Mass Ratios}

The relative contribution of each dry mass component to the total dry mass of the plant was calculated using the following equation: 
Dry mass ratio $=\mathrm{DM}_{\mathrm{C}} / \mathrm{DM}_{\mathrm{T}}$

Where $\mathrm{DM}_{\mathrm{C}}$ is the dry mass of the component part and $\mathrm{DM}_{\mathrm{T}}$ is the total dry mass of the plant. These ratios were calculated for: Leaf mass ratio (LMR), stem mass ratio (SMR), root mass ratio (RMR) and above-ground mass ratio (leaf+stem)(AMR).

\section{Statistical Analysis}

Data were analysed in Genstat 7th edition (VSN International 2004) using the Linear Mixed Model with Residual Maximum Likelihood (REML) estimation (Patterson \& Thompson 1971). The use of REML provides a more powerful method of analysing data with missing values or an unbalanced design (for balanced designs the results of ANOVA and REML are the same). Unlike ANOVA, REML can be used with poisson- as well as normally-distributed data. For consistency and ease of interpretation, all data was analysed using the same REML model as most appropriate for the design and the inclusion of poisson-distributed data. Start-of-experiment measurements of stem diameter and fresh mass were used as co-variates. The fixed effects model used was: browsing $\mathrm{x}$ (presence of competition + competing species) $\mathrm{X}$ competition treatment $\mathrm{x}$ year. The use of presence of 'competition + competing species' enabled the effects of competition and species specific differences to be disentangled. For the dry mass data, block was used as a random factor. For the morphology data, block and pot number were used as random factors. Where data did not meet the assumptions of equality of variance or normally distributed residuals they were either $\log _{10}$ or square root transformed before analysis. For the CI data the Fixed model used was: browsing $\mathrm{X}$ species $\mathrm{X}$ year, and the random factor was block. Comparisons between treatments were made using Fisher's LSD test (Snedecor \& Cochran 1980). 


\section{Results}

\section{Effects of browsing}

There was no significant effect of simulated browsing on the dry mass of the saplings at harvest, or on any of the dry mass ratios within the saplings (Table 1). There was also no main effect of simulated browsing on any of the competition intensities (Table 2). However, there was a significant interaction between species and browsing for ACI. Specifically, while bud-burst browsing reduced the ACI of C. vulgaris, the ACI of M. caerulea was increased when saplings were browsed at bud-burst (Table 3).

There was a significant effect of browsing on leader length (Table 4) with browsed saplings having significantly longer leaders than unbrowsed saplings. Furthermore, summer-clipped saplings had longer leaders than bud-burst clipped saplings (Mean \pm SEM: Unbrowsed $42 \pm 3 \mathrm{~cm}$, late summer browsed $53 \pm 3 \mathrm{~cm}$, bud-burst browsed 49 $\pm 3 \mathrm{~cm}$ ). However, there were no browsing induced differences in the height of the saplings (Table 4). There was also a significant effect of simulated browsing on the number of branches (Table 4). With browsed saplings having fewer branches than unbrowsed saplings. However, this reduction in the number of branches was only significant for saplings growing with $M$. caerulea with browsing applied at bud-burst (S x B interaction, Table 4) (Mean \pm SEM (saplings growing with $M$. caerulea only): Unbrowsed $9.6 \pm 1.4 \mathrm{~cm}$, late summer browsed $8.2 \pm 1.4 \mathrm{~cm}$, bud-burst browsed $6.3 \pm$ $1.3 \mathrm{~cm})$. Browsing did not affect the number of branches for saplings growing with C.vulgaris.

One growing season after simulated browsing was applied, saplings growing with no competition, had a reduced the number of lateral and terminal long shoots, and leaves (Fig. 4, Table 4) compared with the unbrowsed control trees. When interactions from 
M. caerulea were present the effect of browsing on leaf and shoot numbers was altered. Numbers were still reduced for bud-burst browsing. However, late summer browsing no longer reduced numbers of terminal and lateral long shoots, or numbers of leaves. Additionally, interactions from C. vulgaris also removed the bud-burst browsing induced reduction in numbers of leaves and terminal long shoots (Fig. 4, Table 4).

\section{Effects of competition}

\section{M. caerulea}

Sapling dry mass was reduced when in competition with $M$. caerulea roots (Table 1, Fig. 2), although to a lesser extent when shoot and root interactions were present than when just root interactions were present. In fact, in 2003 M. caerulea NRS was indistinguishable from $\mathrm{NN}$ (Fig. 2). The result is that, while $\mathrm{CI}_{T}$ and $\mathrm{CI}_{R}$ experienced from $M$. caerulea were positive, $\mathrm{CI}_{\mathrm{S}}$ was negative (Tables $2 \& 3$ ). This indicates a net facilitative effect of above-ground interactions from $M$. caerulea (i.e. facilitative effects are greater than any negative effects).

Below-ground interactions from M. caerulea did not affect dry mass allocation within the saplings, when compared with the no competition control. However, when aboveand below-ground interactions were present saplings, decreased allocation to leaves and increased allocation to roots (Table 1, Fig. 2).

\section{C. vulgaris}

Root interactions from C. vulgaris reduced sapling dry mass to the same extent as root interactions from M. caerulea (Fig. 4). However, when shoot interactions were added the strength of growth reduction for saplings growing with C. vulgaris was not affected. Consequently, when above- and below-ground interactions were present, $C$ 
vulgaris reduced sapling dry mass to a greater extent than $M$. caerulea. The result of this is that the total Competition intensity $\left(\mathrm{CI}_{\mathrm{T}}\right)$ experienced by the B. pubescens saplings was greater when growing with C. vulgaris than with M. caerulea (Tables 2 \& 3). This was due to differences between the grass and shrub species in the aboveground competition intensity $\left(\mathrm{CI}_{\mathrm{S}}\right)$. $\mathrm{CI}_{\mathrm{S}}$ experienced from $C$. vulgaris was neutral (i.e. not different from zero).

Saplings experiencing both above- and below-ground interactions exhibited similar patterns of dry mass allocation to those growing with only below-ground interactions. The effect was a smaller investment in leaf mass (LMR), and a larger investment in shoot mass (SMR), compared to saplings with no competing species (Table 1, Fig. 2). However, despite the reduced LMR and a reduction in the number of leaves (following the reduction in dry mass), individual leaf size was increased (Fig. 3).

The result of these differences in sapling size and allocation was that, when only below-ground interactions were present saplings growing with C. vulgaris or $M$. caerulea were similar in size. Patterns of dry mass allocation were similar. However, allocation to leaf growth is increased for saplings growing with M. caerulea. When above-ground interactions were added, the species of competing plant had a larger influence on sapling mass and allocation. Saplings growing with C. vulgaris were not influenced by above-ground interactions. However, saplings growing with $M$. caerulea have higher dry mass and increase allocation to roots, at the expense of allocation to leaves, when above-ground interactions are added. The relationship between sapling root mass and shoot mass was similar for saplings growing with no competition, C. vulgaris roots, C. vulgaris roots and shoots, and $M$. caerulea roots (Fig. 3). However, saplings growing with $M$. caerulea roots and shoots showed a 
distinctly different, and much weaker, relationship, exhibiting a lower rate of increase in shoot mass with increasing root mass.

\section{Discussion}

\section{Plant interactions}

Wilson (1998) suggested that woody plants might have a larger competitive effect than grasses, due to woody plants having greater shoot mass and, therefore, greater reduction in light availability. Our findings are consistent with this. We also found that below-ground interactions from $M$. caerulea and $C$. vulgaris reduced sapling dry mass to a greater extent than above-ground interactions. This is also consistent with the prevailing trend (Wilson 1988). The competitive effect of the woody shrub C. vulgaris was found to be greater than that of the grass $M$. caerulea. The difference was apparently due to the reduced above-ground competitive effect of the grass as compared to heather. Betula pubescens saplings responded differently to these contrasting patterns of competition. Sapling responses to competition from $M$. caerulea were explained through responses to the competitive effect of root interactions and the facilitative effect of shoot interactions. Therefore, while saplings responded similarly to root interactions from $C$. vulgaris and $M$. caerulea, sapling responses to full interactions were species-specific.

Sapling responses to $C$. vulgaris were wholly explained by responses to root interactions. This implies that competition was for nutrients. However, according to the balanced-growth hypothesis and optimal foraging theory, reductions in nutrient availability should result in increased allocation to roots in order to better utilise competition-induced nutrient limitation (Tilman 1988, Shipley and Meziane 2002). However, there was no evidence that this was the case in the present study. Below 
ground competition from $C$. vulgaris or $M$. caerulea had little effect on allocation to roots. Previous work has found conflicting evidence for the application of the balanced-growth hypothesis to below-ground competitive interactions (e.g. Muller $e t$ al 2000, Shipley \& Mezaine 2002, Cahill 2003). Our findings support Cahill's (2003) assertion that plant root growth is not solely a product of nutrient availability. Calhill (2003) highlighted the multi-functionality of roots as a complicating factor when predicting allocation responses to below-ground competition, our study serves to reinforce this. Additionally, root growth is constrained by the availability of space to a greater extent than shoot growth (Grime \& Mackey 2002). This limits the plasticity of root growth in response to environmental variation of resource availability. The addition of competing plant roots may further constrain root growth, and confound the response of sapling roots to the reduction in below-ground resource availability. Furthermore, in response to the facilitative effect of $M$. caerulea shoots, saplings decreased allocation to leaves and increased root allocation. This suggests that shoot interactions increased the acquisition of carbon, improving root growth. However, the mechanism for the facilitative effect of $M$. caerulea shoots is not clear.

Treatment effects on plant slant size may influence the allocation of growth (Müller et al. 2000). This appears to be the case for the majority of the competitive interactions, although this does not negate the importance of the lack of increase in root mass due to below-ground interactions. However, saplings growing with root and shoot interactions from $M$. caerulea show a distinctly different relationship between root and shoot mass when compared to the other saplings. This suggests that, for the effect of M. caerulea shoots, the differences proportions of dry mass of sapling roots and shoots are not due to treatment effects on sapling size. Therefore, we suggest that the response of saplings to $M$. caerulea shoots and roots is intrinsically different to 
their response to the other the competitive treatments. It seems likely that this is due to the facilitative nature of the above-ground interaction. This highlights the importance of considering the multi-factorial mechanisms by which plants influence their neighbours. Particularly important are the potentially antagonistic interactions between competitive and facilitative effects, each of which may be acting on a number of different limiting processes.

\section{Herbivory}

We found no overall significant effect of $50 \%$ of new growth herbivory on the dry mass of the saplings, one year after browsing damage was induced. This is consistent with previous studies on Betula species (Bergström \& Danell 1987; Hjältén, Danell \& Ericson 1993; Hester et al. 2004), indicating that B. pubescens was able to compensate for the removal of tissues at this level of simulated herbivory. We also found no effect of herbivory on CI, suggesting that the lack of browsing effect translated into a lack of effect of browsing on competitive ability. It has been suggested that the ability to compensate for herbivory may not necessarily increase plant fitness, and may be detrimental to the plant (Hjälten et al 1993). This may be related to plant productivity. For example, Olofsson et al. (2002) found that herbivory increased CI in relatively unproductive plant communities in snowbeds. However, in productive tall herb meadow communities they found no effect of herbivory on CI. In the present study, the ability of the saplings to compensate for browsing damage did not affect their competitive ability. This could be explained through their fast growth and high degree of phenotypic plasticity. Despite the lack of impact of simulated browsing on final dry mass, we found evidence that the saplings in our study altered their morphology to compensate for browsing damage, for example by producing longer leading shoots and altering the numbers and proportions 
of leaves and long and short shoots. These morphological changes were influenced by the competition treatments, implying that the saplings are able to alter their response to herbivory depending on the influence of competition. This enabled the saplings to compensate for browsing damage, despite the strong competitive effect of interacting plants, resulting in no significant interaction effects between competition and herbivory for sapling growth.

In conclusion, our results indicate that that the woody shrub $C$ vulgaris reduces birch sapling growth to a greater extent than the deciduous grass $M$. caerulea, primarily due to differences in above-ground competition. The mechanism for these differences is unclear. However, above-ground interactions from $M$. caerulea alter patterns of sapling growth allocation, suggesting an alteration in the relative sink sizes. We found very little effect for herbivory on sapling dry mass, or overall response to competition, due to their ability to alter growth and morphology plastically. These results suggest that the rate of establishment success of $B$. pubescens will be strongly dependent on the vegetation in which it is growing, but that this effect is littlemodified by moderate levels of browsing.

\section{Acknowledgements}

We would like to thank the following for their assistance: Jim McGregor, Janet Woo, Ruth Gill, Jasmine Ross, Renate Wendler, Emily Green, Kirsi Neuavonon, Allen Simm and other staff at the Macaulay Institute and University of Aberdeen. BIOSS provided assistance with statistical analysis. Jonathan Millett was funded by the Macaulay Development Trust. PM and AH were funded by SEERAD. 


\section{References}

Atkinson, M.D. (1992). Biological flora of the British Isles No. 175. Betula pendula Roth (B. verrucosa Ehrh. and B. pubescens Ehrh). Journal of Ecology, 80, 837-870.

Belcher, J.W., Keddy, P.A. \& Twolan-Strutt, L. (1995). Root and shoot competition intensity along a soil depth gradient. Journal of Ecology, 83, 673-682.

Bergström, R. \& Danell, K. (1987). Effects of simulated winter browsing by moose on morphology and biomass of 2 birch species. Journal of Ecology, 75, 533-544.

Bonser, S.P. \& Reader, R.J. (1995). Plant competition and herbivory in relation to vegetation biomass. Ecology 76, 2176-2183.

Calhill Jr, J.F. (2003). Lack of relationship between below-ground competition and allocation to roots in 10 grassland species. Journal of Ecology, 91, 532-540.

Callaway, R.M. \& Walker, L.R. (1997). Competition and facilitation: a synthetic approach to interactions in plant communities. Ecology, 78, 1958-1965.

Campbell, B.D. \& Grime, J.P. (1992). An experimental test of plant strategy theory. Ecology, 73, 15-19.

Casper, B.B. \& Jackson, R.B. (1997). Plant competition underground. Annual Review of Ecology and Systematics, 28, 545-570.

Clements, F.E., Weaver, J.E. \& Hanson, H.C. (1929). Plant competition: an analysis of community functions. Washington, D.C.: Carnegie Institute.

Connell, J.K. (1990). Apparent versus "real" competition in plants. In: J.B. Grace \& D. Tilman (Eds.), Perspectives on plant competition (pp. 9-26). San Diego: Academic Press.

Cook, S.J. \& Ratcliff, D. (1984). A study of the effects of root and shoot competition on the growth of green panic (Panicum maximum var. tricoglume) seedlings in an existing grassland using root exclusion tubes. Journal of Applied Ecology, 21, 971982.

Crawley, M.J. (2000). Plant-herbivore dynamics. In: M.J. Crawley (Ed.), Plant Ecology. (2 ${ }^{\text {nd }}$ ed.) (pp. 401-474). Oxford: Blackwell Science Ltd.

Danell, K. \& Bergström, R. (2002). Mammalian herbivory in terrestrial environments. In: C.M. Herra \& O. Pellmyr (Eds.), Plant-Animal Interactions (pp 107-131). Oxford: Blackwell Science Ltd.

Donald, C.M. (1958). The interaction of competition for light and for nutrients. Australian Journal of Agricultural Research, 9, 421-151.

Dormann, C.F., Van der Wal, R. \& Bakker, J.P. (2000). Competition and herbivory during salt marsh succession: the importance of forb growth strategy. Journal of Ecology, 88, 571-583. 
Farrar, J.F. (1999). Acquisition, partitioning and loss of carbon. In: M.C. Press, J.D. Scholes \& M.G. Barker (Eds.), Physiological Plant Ecology (pp 25-43). Oxford: Blackwell Science Ltd.

Gimingham, C.H. (1960). Biological Flora of the British Isles. Calluna vulgaris (L.) Hull. Journal of Ecology, 48 455-483.

Grace, J.B. (1995). On the measurement of plant competition intensity. Ecology, 76, 305-308.

Grace, J.B. \& Tilman, D. (1990). Perspectives on Plant Competition. San Diego: Academic Press Inc.

Grime, J.P. (1973). Competitive exclusion in herbaceous vegetation. Nature, 242, 344-347.

Grime, J.P. (1979). Plant Strategies and Vegetation Processes. Chichester: John Wiley \& Sons.

Grime, J.P. \& Mackey, J.M.L. (2002). The role of plasticity in resource capture by plants. Evolutionary Ecology, 16, 299-307.

Harper, J.L. (1977). Population Biology of Plants. London: Academic Press.

Hester, A.J., Bergman, M., Iason, G.R. \& Moean, J. (in press). Impacts of large herbivores on plant community structure and dynamics. In: K. Danell, R. Bergström, P. Duncan, J. Pastor \& H. Olff (Eds.), Large Herbivore Ecology and Ecosystem Dynamics. Cambridge: Cambridge University Press.

Hester, A.J., Edenius, L., Buttenschon, R.M. \& Kuiters, A.T. (2000). Interactions between forests and herbivores: the role of controlled grazing experiments. Forestry, 73, 381-391.

Hester, A.J., Millard, P., Baillie, G.J. \& Wendler, R. (2004). How does timing of browsing affect above- and below-ground growth of Betula pendula, Pinus sylvestris and Sorbus aucuparia? Oikos, 105, 536-550.

Hester, A.J., Mitchell, F.J.G. \& Kirby, K.J. (1996). Effects of season and intensity of sheep grazing on tree regeneration in a British upland woodland. Forest Ecology and Management, 88, 99-106.

Hjältén, J., Danell, K. \& Ericson, L. (1993). Effects of simulated herbivory and intraspecific competition on the compensatory ability of birches. Ecology, 74, 11361142.

Holl, K.D. (1998). Effects of above-and below-ground competition of shrubs and grass on Calophyllum brasiliense (Camb.) seedling growth in abandoned tropical pasture. Forest Ecology and Management, 109, 187-195.

Holzapfel, C.H. \& Mahall, B.E. (1999). Bidirectional facilitation and interference between shrubs and annuals in the Mojave desert. Ecology, 80, 1747-1761. 
Huntley, N. (1991). Herbivores and the dynamics of communities and ecosystems. Annual review of Ecology and Systematics, 22, 477-503.

Kuiters, A.T. \& Slim, P.A. (2002). Regeneration of mixed deciduous forest in a Dutch forest-heathland, following a reduction of ungulate densities. Biological Conservation, 105, 65-74.

Louda, S.M., Keeler, K.H., \& Holt, R.D. (1990). Herbivore influences on plant performance and competitive interactions. In: J.B. Grace \& D. Tilman (Eds.), Perspectives on plant competition (pp 413-444). San Diego: Academic Press Inc.

McPhee, C.S. \& Aarssen, L.W. (2001). The separation of above- and below-ground competition in plants - A review and critique of methodology. Plant Ecology, 152, 119-136.

Meiners, S.J. \& Handel, S.N. (2000). Additive and non-additive effects of herbivory and competition on tree seedling mortality, growth and allocation. American Journal of Botany, 87, 1821-1826.

Millard, P. \& Proe, M.F. (1991). Leaf demography and the seasonal internal cycling of nitrogen in sycamore (Acer pseudoplatinus L) seedlings in relation to nitrogen supply. New Phytologist, 117, 587-596.

Millard, P., Hester, A.J., Wendler, R. \& Baillie, G.J. (2001). Interspecific defoliation responses of trees depends on sites of winter nitrogen storage. Functional Ecology, $15,535-543$.

Millett, J., Hester, A.J., Millard, P. \& McDonald, A.J.S. (in press). How do different competing species influence the response of Betula pubescens Ehrh. To browsing? Basic and Applied Ecology.

Müller, I., Schmidt, B. \& Weiner, J. (2000). The effect of nutrient availability on biomass allocation patterns in 27 species of herbaceous plants. Perspectives in Plant Ecology, Evolution and Systematics, 3, 115-127.

Olofsson, J., Moen, J. \& Oksanen, L. (2002). Effects of herbivory on competition intensity in two arctic-alpine tundra communities with different productivity. Oikos, 96, 265-272.

Peltzer, D.A. \& Köchy, M. (2001). Competitive effects of grasses and woody plants in mixed-grass prairie. Journal of Ecology, 89, 519-527.

Reader, R.J. (1992). Herbivory, competition, plant mortality and reproduction on a topographic gradient in an abandoned pasture. Oikos, 65, 414-418

Reader, R.J., Wilson, S.D., Belcher, J.W., Wisheu, P.A., Keddy, P.A., Tilman, D., Morris, E.C., Grace, J.B., McGraw, J.B., Olff, H., Turkington, R., Klein, E., Leung, Y., Shipley, B., van Hulst, R., Johansson, M.E., Nilsson, C., Gurevitch, J., Grigulis, K. \& Beisner, B.E. (1994). Intensity of plant competition in relation to neighbour biomass, an intercontinental study with Poa pratensis. Ecology, 75, 1753-1760. 
Reynolds, H. \& Antonio, C. (1996). The ecological significance of plasticity in root weight ratio in response to nitrogen: opinion. Plant and Soil, 185, 75-97.

Shipley, B. \& Meziane, D. (2002). The balanced-growth hypothesis and the allometry of leaf and root biomass allocation. Functional Ecology, 16, 326-331.

Snaydon, R.W. \& Howe, C.D. (1986). Root and shoot competition between established ryegrass and invading grass seedlings. Journal of Applied Ecology, 23, 667-674.

Snedecor, G.W. \& Cochran, W.G. (1980). Statistical Methods. ( $7^{\text {th }}$ edition). Iowa: Iowa State University Press.

Taylor, K., Rowland, A.P. \& Jones, H.E. (2001). Biological flora of the British Isles No. 216. Molinia caerulea (L.) Moench. Journal of Ecology, 89 126-144.

Tilman, D. (1988). Plant strategies and the dynamics and structure of plant communities. Princeton: Princeton University Press.

Twolan-Strutt, L. \& Keddy, P.A. (1996). Above- and below-ground competition intensity in two contrasting wetland plant communities. Ecology, 77, 259-270.

Van Hees, A.F.M., Kuiters, A.T. \& Slim, P.A. (1996). Growth and development of silver birch, pedunculate oak and beech as affected by deer browsing. Forest Ecology and Management, 88, 55-63.

VSN International. (2004). Genstat, release 7.2

Weigelt, A. \& Jolliffe, P. (2003). Indices of plant competition. Journal of Ecology, 91, 707-720.

Wilson, J.B. (1988). Shoot competition and root competition. Journal of Applied Ecology, 25, 279-296.

Wilson, J.B. (1993). Belowground competition in forest and prairie. Oikos, 68, 146150.

Wilson, S.D. (1998). Competition between grasses and woody plants. Population Ecology of Grasses (ed. G. Cheplick), pp. 231-254. Cambridge University Press, Cambridge.

Wilson, S.D. \& Tilman, D. (1991). Components of plant competition along an experimental gradient of nitrogen availability. Ecology, 72, 1050-1065. 
1 Table 1 Results of univariate residual maximum likelihood (REML) analysis of B. pubescens sapling growth and allocation. Presented are the 2 Wald Statistic (WS) and significances: ( ${ }^{\mathrm{NS}}-P>0.05, *-P<0.05, * *-P<0.01$, *** $-P<0.001$ ) for the main effects of, and interactions 3 between, $\mathrm{B}=$ browsing (Late summer/spring/none), $\mathrm{C}=$ competition (present/absent), $\mathrm{S}=$ competing species $($ Calluna/Molinia), $\mathrm{L}=$

4 competition type (below ground/above and below ground), $T$ = time (autumn 2003/spring2004).

\begin{tabular}{|c|c|c|c|c|c|c|c|c|c|c|c|}
\hline & & $\begin{array}{l}\text { Whole tree } \\
\text { dry mass }\end{array}$ & $\begin{array}{l}\text { Leaf dry } \\
\text { mass }^{1}\end{array}$ & $\begin{array}{l}\text { New-growth } \\
\text { dry mass }\end{array}$ & $\begin{array}{l}\text { Old growth } \\
\text { dry mass }{ }^{1}\end{array}$ & $\begin{array}{l}\text { Root dry } \\
\text { mass }^{1}\end{array}$ & $\begin{array}{c}\text { Above- } \\
\text { ground dry } \\
\text { mass }^{1}\end{array}$ & $\begin{array}{c}\text { Above- } \\
\text { ground MR }\end{array}$ & LMR & SMR & $\mathrm{RMR}^{2}$ \\
\hline & d.f. & WS & WS & WS & WS & WS & WS & WS & WS & WS & WS \\
\hline B & 2,153 & $1.96^{\mathrm{NS}}$ & $0.91^{\mathrm{NS}}$ & $0.50^{\mathrm{NS}}$ & $2.16^{\mathrm{NS}}$ & $0.98^{\mathrm{NS}}$ & $1.49^{\mathrm{NS}}$ & $1.37^{\mathrm{NS}}$ & $0.01^{\text {NS }}$ & $0.88^{\text {NS }}$ & $0.53^{\mathrm{NS}}$ \\
\hline C & 1,153 & $47.49^{\star \star *}$ & $64.91^{\star * *}$ & $8.40^{\text {** }}$ & $50.71^{\star * *}$ & $41.06^{\star \star *}$ & $52.96^{\star \star \star}$ & $0.03^{\mathrm{NS}}$ & $4.55^{\star}$ & $1.56^{\mathrm{NS}}$ & $0.02^{\mathrm{NS}}$ \\
\hline S & 1,153 & $26.75^{\star \star \star}$ & $47.46^{\star \star \star}$ & $0.85^{\mathrm{NS}}$ & $24.41^{\star \star \star}$ & $26.91^{\star \star \star}$ & $22.66^{\star \star \star}$ & $0.50^{\mathrm{NS}}$ & $5.24^{*}$ & $4.29 *$ & $0.89^{N S}$ \\
\hline $\mathrm{L}$ & 1,153 & $1.88^{\mathrm{NS}}$ & $4.43^{\star}$ & $1.43^{\mathrm{NS}}$ & $0.04^{\mathrm{NS}}$ & $4.88^{\star}$ & $0.24^{\mathrm{NS}}$ & $7.23^{\star \star}$ & $0.39^{\mathrm{NS}}$ & $7.80^{\star \star}$ & $6.70^{\star *}$ \\
\hline $\mathrm{T}$ & 1,153 & $11.31^{\star \star *}$ & $0.02^{\mathrm{NS}}$ & 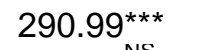 & $201.03^{\star \star \star}$ & $26.64^{\star \star *}$ & $6.26^{\star}$ & $21.55^{\star \star \star}$ & $53.05^{\star \star *}$ & $0.00^{\mathrm{NS}}$ & $26.10^{\star \star \star x}$ \\
\hline $\mathrm{B} \times \mathrm{C}$ & 2,153 & $0.58^{\mathrm{NS}}$ & $3.43^{\mathrm{NS}}$ & $1.74^{\mathrm{NS}}$ & $1.11^{\mathrm{NS}}$ & $0.13^{\mathrm{NS}}$ & $0.64^{\mathrm{NS}}$ & $0.08^{\mathrm{NS}}$ & $7.45^{\star}$ & $3.97^{\mathrm{NS}}$ & $0.37^{\mathrm{NS}}$ \\
\hline $\mathrm{B} \times \mathrm{S}$ & 2,153 & $4.93^{\mathrm{NS}}$ & $5.99 *$ & $1.45^{\mathrm{NS}}$ & $3.03^{\mathrm{NS}}$ & $5.40^{\mathrm{NS}}$ & $4.04^{\mathrm{NS}}$ & $4.69^{\mathrm{NS}}$ & $1.37^{\mathrm{NS}}$ & $4.35^{\mathrm{NS}}$ & $4.88^{\mathrm{NS}}$ \\
\hline$B \times L$ & 2,153 & $0.68^{\mathrm{NS}}$ & $0.94^{\mathrm{NS}}$ & $0.97^{\mathrm{NS}}$ & $2.10^{\mathrm{NS}}$ & $0.31^{\mathrm{NS}}$ & $1.12^{\mathrm{NS}}$ & $2.36^{\mathrm{NS}}$ & $0.78^{\mathrm{NS}}$ & $0.91^{\mathrm{NS}}$ & $2.34^{\mathrm{NS}}$ \\
\hline SxL & 1,153 & $4.37^{\star}$ & $0.77^{\mathrm{NS}}$ & $3.04^{\mathrm{NS}}$ & $4.50^{*}$ & $3.40^{\mathrm{NS}}$ & $4.91^{\star}$ & $0.00^{\mathrm{NS}}$ & $4.66^{\star}$ & $2.13^{\mathrm{NS}}$ & $0.08^{\mathrm{NS}}$ \\
\hline $\mathrm{TxB}$ & 2,153 & $1.27^{\mathrm{NS}}$ & $1.06^{\mathrm{NS}}$ & $2.01^{\mathrm{NS}}$ & $0.27^{\mathrm{NS}}$ & $1.69^{\mathrm{NS}}$ & $0.58^{\mathrm{NS}}$ & $1.14^{\mathrm{NS}}$ & $0.16^{\mathrm{NS}}$ & $1.41^{\mathrm{NS}}$ & $0.94^{\mathrm{NS}}$ \\
\hline $\mathrm{TxC}$ & 1,153 & $0.04^{\mathrm{NS}}$ & $0.06^{\mathrm{NS}}$ & $6.72^{\star}$ & $0.28^{\mathrm{NS}}$ & $0.05^{\mathrm{NS}}$ & $0.16^{\mathrm{NS}}$ & $0.52^{\mathrm{NS}}$ & $0.04^{\mathrm{NS}}$ & $0.71^{\mathrm{NS}}$ & $0.68^{\mathrm{NS}}$ \\
\hline TxS & 1,153 & $1.19^{\mathrm{NS}}$ & $0.00^{\mathrm{NS}}$ & $11.50^{\star \star \star}$ & $0.39^{\mathrm{NS}}$ & $1.40^{\mathrm{NS}}$ & $0.79^{\mathrm{NS}}$ & $1.49^{\mathrm{NS}}$ & $3.66^{\mathrm{NS}}$ & $0.03^{\mathrm{NS}}$ & $0.89^{\mathrm{NS}}$ \\
\hline $\mathrm{TXL}$ & 1,153 & $0.49^{\mathrm{NS}}$ & $0.19^{N S}$ & $0.49^{N S}$ & $1.91^{\mathrm{NS}}$ & $0.40^{\mathrm{NS}}$ & $0.71^{\mathrm{NS}}$ & $0.01^{\mathrm{NS}}$ & $2.23^{\mathrm{NS}}$ & $1.18^{\mathrm{NS}}$ & $0.03^{\mathrm{NS}}$ \\
\hline
\end{tabular}

$5 \quad{ }^{1}$ Log transformed, ${ }^{2}$ Square root transformed

6 All three and four way interactions were not significant and are not shown. 
7 Table 2 Results of the univariate REML analysis of the absolute (ACI) and relative

8 (RCI) competition intensity experienced by $B$. pubescens saplings. Presented are the

9 Wald Statistic from the REML analysis and the significance $\left({ }^{\mathrm{NS}}-P>0.05,{ }^{*}-P<\right.$

$100.05, * *-P<0.01, * * *-P<0.001)$ for differences between species (S), competition

11 intensity type $(\mathrm{Cl})$ and browsing $(\mathrm{B})$, and interactions between the three.

\begin{tabular}{cccc}
\hline & & $\mathrm{ACl}$ & $\mathrm{RCl}$ \\
\hline $\mathrm{B}$ & 2,130 & $0.59^{\mathrm{NS}}$ & $1.70^{\mathrm{NS}}$ \\
$\mathrm{Cl}$ & 2,130 & $103.02^{\star \star \star}$ & $66.17^{\star \star \star}$ \\
$\mathrm{S}$ & 1,130 & $14.25^{\star \star \star}$ & $14.03^{\star \star \star}$ \\
$\mathrm{S} \times \mathrm{Cl}$ & 2,130 & $2.43^{\mathrm{NS}}$ & $1.94^{\mathrm{NS}}$ \\
$\mathrm{S} \times \mathrm{B}$ & 2,130 & $6.13^{\star}$ & $1.84^{\mathrm{NS}}$ \\
$\mathrm{Cl} \mathrm{B}$ & 4,130 & $5.58^{\mathrm{NS}}$ & $1.31^{\mathrm{NS}}$ \\
$\mathrm{SxClxB}$ & 4,130 & $1.82^{\mathrm{NS}}$ & 1.25 \\
\hline
\end{tabular}

12

13

14

15 
16 Table 3 Absolute $(\mathrm{ACl})$ and relative $(\mathrm{RCl})$ competition intensity experienced by $B$.

17 pubescens saplings growing with two different species. Presented are mean \pm SED

18 for total $\left(\mathrm{Cl}_{\mathrm{T}}\right)$, root $\left(\mathrm{Cl}_{\mathrm{R}}\right)$ and shoot $\left(\mathrm{Cl}_{\mathrm{S}}\right)$ competition intensity for saplings growing

19 in $M$. caerulea or C. vulgaris with three different simulated browsing treatments.

\begin{tabular}{cccccccc}
\hline \multirow{2}{*}{ Species } & Browsing & $\mathrm{Cl}_{\mathrm{T}}$ & $\mathrm{ACl}$ & $\mathrm{Cl}_{\mathrm{R}}$ & $\mathrm{Cl}_{\mathrm{S}}$ & $\mathrm{Cl}_{\mathrm{T}}$ & $\mathrm{Cl}$ \\
\hline \multirow{3}{*}{ Molinia } & None & $25.6 \pm 13.2$ & $37.0 \pm 11.0$ & $-12.8 \pm 10.1$ & $0.1 \pm 0.2$ & $0.4 \pm 0.1$ & $-0.3 \pm 0.2$ \\
& Late summer & $23.0 \pm 12.0$ & $48.4 \pm 9.0$ & $-24.9 \pm 7.1$ & $0.1 \pm 0.2$ & $0.5 \pm 0.1$ & $-0.3 \pm 0.1$ \\
& Bud-burst & $39.3 \pm 12.6$ & $51.1 \pm 15.0$ & $-12.0 \pm 13.1$ & $0.3 \pm 0.2$ & $0.4 \pm 0.2$ & $-0.2 \pm 0.1$ \\
& & & & & & & \\
\multirow{4}{*}{ Calluna } & None & $67.4 \pm 8.7$ & $47.8 \pm 13.1$ & $27.7 \pm 20.5$ & $0.7 \pm 0.1$ & $0.5 \pm 0.1$ & $0.1 \pm 0.2$ \\
& Late summer & $75.0 \pm 10.7$ & $64.0 \pm 8.7$ & $6.2 \pm 9.8$ & $0.7 \pm 0.0$ & $0.6 \pm 0.0$ & $0.1 \pm 0.1$ \\
& Bud-burst & $33.3 \pm 14.1$ & $48.0 \pm 16.1$ & $-11.0 \pm 6.9$ & $0.3 \pm 0.2$ & $0.5 \pm 0.2$ & $-0.1 \pm 0.1$ \\
\hline
\end{tabular}


21 Table 4 Results of univariate residual maximum likelihood (REML) analysis of $B$. pubescens sapling morphology. Presented are the Wald

22 Statistic (WS) and significances $\left({ }^{\mathrm{NS}}-P>0.05, *-P<0.05, * *-P<0.01, * * *-P<0.001\right)$ for the main effects of, and interactions between, $\mathrm{B}$

23 = browsing (Late summer/spring/none), $\mathrm{C}=$ competition (present/absent), $\mathrm{S}=$ competing species (Calluna/Molinia), $\mathrm{L}=$ competition type

24 (below ground/above and below ground), $\mathrm{T}=$ time (autumn 2003/spring2004).

\begin{tabular}{|c|c|c|c|c|c|c|c|c|c|c|c|c|}
\hline & & $\begin{array}{c}\text { Terminal long } \\
\text { shoots }^{2}\end{array}$ & $\begin{array}{c}\text { Stem } \\
\text { diameter }\end{array}$ & $\begin{array}{c}\text { Short } \\
\text { shoots }^{2}\end{array}$ & $\begin{array}{c}\text { Lateral long } \\
\text { shoots }^{1}\end{array}$ & $\begin{array}{l}\text { Leader } \\
\text { length }^{2}\end{array}$ & $\begin{array}{c}\text { Distance to } \\
\text { lowest branch }\end{array}$ & $\begin{array}{l}\text { Number of } \\
\text { branches }^{2}\end{array}$ & $\begin{array}{c}\text { Number of } \\
\text { leaves }\end{array}$ & Length & $\begin{array}{l}\text { Canopy } \\
\text { cover }^{1}\end{array}$ & $\begin{array}{c}2^{\circ} \text { lateral } \\
\text { long shoots }\end{array}$ \\
\hline & d.f. & WS & WS & WS & WS & WS & WS & WS & WS & WS & WS & WS \\
\hline$B$ & 2,153 & $3.99^{\mathrm{NS}}$ & $1.08^{\mathrm{NS}}$ & $0.90^{\mathrm{NS}}$ & $13.06^{* *}$ & $15.99 * \star$ & $1.96^{\mathrm{NS}}$ & $15.30^{\star \star \star}$ & $4.33^{\mathrm{NS}}$ & $3.28^{\mathrm{NS}}$ & $1.00^{\mathrm{NS}}$ & $2.03^{\mathrm{NS}}$ \\
\hline C & 1,153 & $75.25^{\star \star \star}$ & $45.17^{\star \star \star}$ & $40.80^{\star \star *}$ & $71.27^{\star \star \star}$ & $4.36^{\star}$ & $12.93^{\star \star \star}$ & $30.34^{* * *}$ & $141.38^{\star \star \star}$ & $28.72^{\star \star \star}$ & $79.80^{\star \star \star}$ & $22.95^{\star \star \star}$ \\
\hline$S$ & 1,153 & $80.58^{\star \star \star}$ & $15.45^{\star \star \star}$ & $47.36^{\star \star \star}$ & $71.68^{\star \star \star}$ & $1.08^{\mathrm{NS}}$ & $2.27^{\mathrm{NS}}$ & $17.02^{\star * \star}$ & $118.44^{\star \star *}$ & $22.71^{\star \star \star}$ & $53.22^{\star \star \star}$ & $11.05^{\star \star \star}$ \\
\hline L & 1,153 & $2.28^{\mathrm{NS}}$ & $0.69^{\mathrm{NS}}$ & $3.25^{\mathrm{NS}}$ & $1.54^{\mathrm{NS}}$ & $2.05^{\mathrm{NS}}$ & $1.59^{\mathrm{NS}}$ & $0.01^{\mathrm{NS}}$ & $1.52^{\mathrm{NS}}$ & $2.84^{\mathrm{NS}}$ & $0.51^{\mathrm{NS}}$ & $0.03^{\mathrm{NS}}$ \\
\hline $\mathrm{T}$ & 1,153 & $198.28^{\star \star \star}$ & $33.55^{\star \star \star}$ & $306.45^{\star \star \star}$ & $341.97^{\star \star *}$ & $504.14^{\star \star *}$ & $13.34^{\star \star *}$ & $1065.25^{\star \star *}$ & $259.75^{\star \star \star}$ & $46.61^{\star \star *}$ & $23.09 * * *$ & ND \\
\hline $\mathrm{B} \times \mathrm{C}$ & 2,153 & $0.57^{\mathrm{NS}}$ & $0.02^{\mathrm{NS}}$ & $4.93^{\mathrm{NS}}$ & $0.26^{\mathrm{NS}}$ & $3.64^{\mathrm{NS}}$ & $1.46^{\mathrm{NS}}$ & $0.46^{\mathrm{NS}}$ & $2.17^{\mathrm{NS}}$ & $2.13^{\mathrm{NS}}$ & $2.89^{\mathrm{NS}}$ & $0.72^{\mathrm{NS}}$ \\
\hline $\mathrm{B} \times \mathrm{S}$ & 2,153 & $24.71^{\star \star \star}$ & $3.33^{\mathrm{NS}}$ & $7.82^{\star}$ & $10.76^{\star \star}$ & $0.31^{\mathrm{NS}}$ & $1.46^{\mathrm{NS}}$ & $8.24^{\star *}$ & $10.62^{\star *}$ & $0.48^{\mathrm{NS}}$ & $1.48^{\mathrm{NS}}$ & $5.60^{\mathrm{NS}}$ \\
\hline$B \times L$ & 2,153 & $0.29^{\mathrm{NS}}$ & $0.59^{\mathrm{NS}}$ & $0.60^{\mathrm{NS}}$ & $2.23^{\mathrm{NS}}$ & $0.64^{\mathrm{NS}}$ & $1.58^{\mathrm{NS}}$ & $3.25^{\mathrm{NS}}$ & $1.05^{\mathrm{NS}}$ & $1.44^{\mathrm{NS}}$ & $0.41^{\mathrm{NS}}$ & $1.22^{\mathrm{NS}}$ \\
\hline SxL & 1,153 & $0.05^{\mathrm{NS}}$ & $3.82^{\mathrm{NS}}$ & $1.35^{\mathrm{NS}}$ & $0.20^{\mathrm{NS}}$ & $0.64^{\mathrm{NS}}$ & $0.13^{\mathrm{NS}}$ & $0.52^{\mathrm{NS}}$ & $1.86^{\mathrm{NS}}$ & $3.34^{\mathrm{NS}}$ & $1.67^{\mathrm{NS}}$ & $3.50^{\mathrm{NS}}$ \\
\hline$T \times B$ & 2,153 & $1.10^{\mathrm{NS}}$ & $1.67^{\mathrm{NS}}$ & $0.21^{\mathrm{NS}}$ & $0.05^{\mathrm{NS}}$ & $0.59^{\mathrm{NS}}$ & $1.09^{\mathrm{NS}}$ & $1.12^{\mathrm{NS}}$ & $0.59^{\mathrm{NS}}$ & $5.45^{\mathrm{NS}}$ & $0.35^{\mathrm{NS}}$ & ND \\
\hline $\mathrm{TxC}$ & 1,153 & $40.15^{\star \star \star}$ & $0.07^{\mathrm{NS}}$ & $33.13^{\star \star \star}$ & $5.69^{\star}$ & $4.40^{*}$ & $2.20^{\mathrm{NS}}$ & $1.08^{\mathrm{NS}}$ & $12.07^{\star * *}$ & $5.87^{\star \star}$ & $0.74^{\mathrm{NS}}$ & ND \\
\hline TxS & 1,153 & $79.76^{\star \star \star}$ & $2.69^{\mathrm{NS}}$ & $55.22^{\star \star \star}$ & $9.40^{\star *}$ & $24.82^{\star \star \star}$ & $0.00^{\mathrm{NS}}$ & $4.44^{\star}$ & $42.86^{\star \star \star}$ & $3.96^{\star}$ & $8.41^{\star \star}$ & ND \\
\hline $\mathrm{TxL}$ & 1,153 & $2.49^{\mathrm{NS}}$ & $0.10^{\mathrm{NS}}$ & $2.79^{\mathrm{NS}}$ & $0.19^{\mathrm{NS}}$ & $0.14^{\mathrm{NS}}$ & $0.01^{\mathrm{NS}}$ & $0.08^{\mathrm{NS}}$ & $4.15^{\star}$ & $11.48^{\star \star \star}$ & $1.52^{\mathrm{NS}}$ & ND \\
\hline
\end{tabular}

$25{ }^{1}$ Log transformed, ${ }^{2}$ Square root transformed

26 All three and four way interactions were not significant and are not shown 
Figure 1 Competition treatments imposed on B. pubescens saplings. Saplings either had (a) no interactions with surrounding vegetation (NN); (b) above- and below-ground interactions (NRS) or (c) below-ground interactions only (NR).
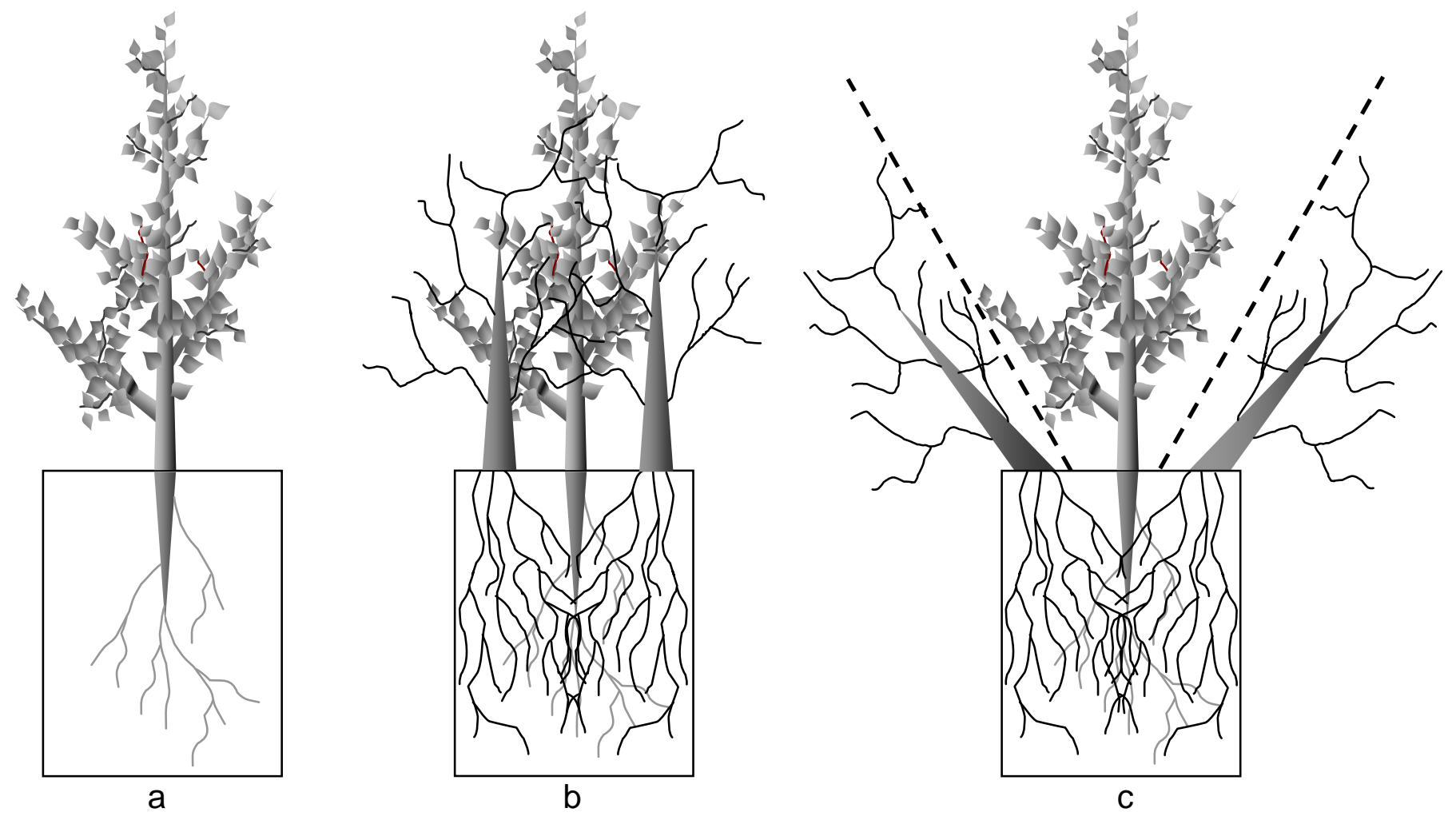
Figure 2 Dry mass of component parts B. pubescens saplings growing alone or with below-ground or above- and below-ground interactions from either M. caerulea or C. vulgaris. Bars show mean \pm SEM for whole tree dry mass. Letters above bars indicate differences between whole tree dry mass. Letters within bars indicate differences between saplings in the dry mass of that component part (Fisher's LSD, $P<0.05)$. Data were transformed before analysis (see Table 1).

120

\section{$\square$ Leaves}

$\square$ New growth

100

$\square$ Old growth

Roots



40

20

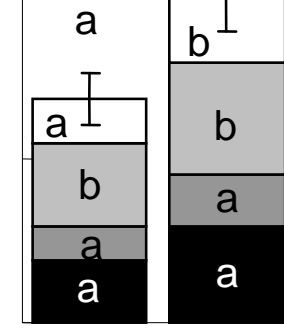

Calluna Molinia

Root interactions (NR) bc

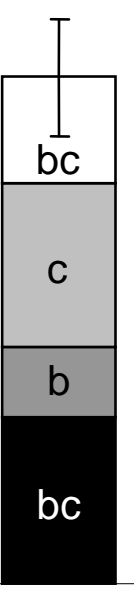

Calluna Molinia

Root and shoot interactions (NRS)

2003
No competing plants (NN)
Root interactions (NR)
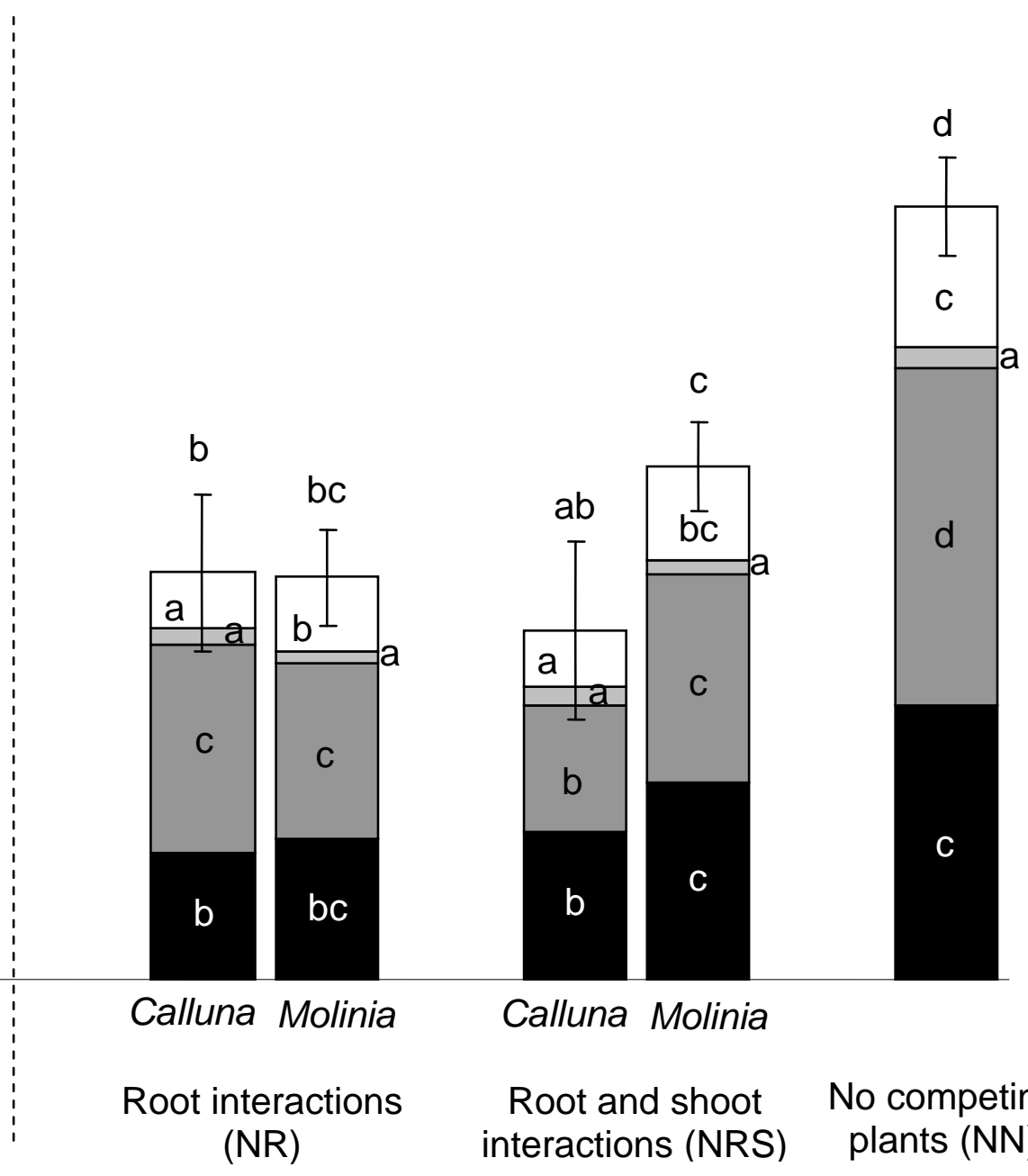

Root and shoot

No competing interactions (NRS) plants (NN) 
Relationship between root mass and above-ground mass of $B$. pubescens saplings growing with five different competition treatments. Presented are values for individual saplings and the fitted linear least-squares regression line. Competition treatments are: no competing vegetation (6), competition from C. vulgaris ( $\circ \& \bullet$ ) and competition from M. caerulea $(\square \& \square)$. Where competing plants are present open symbols represent only interactions form neighbours roots (NR) ( $\square \& \circ$ ) and filled symbols represent interactions from neighbours roots and shoots (NRS) ( \& \& $\bullet$ ). No competition: $y=1.09 x+26.1, \mathrm{r}^{2}=0.67(-)$, C. vulgaris NR: $y=1.3241 x+8.3536$,

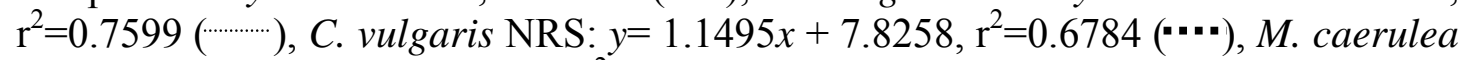
45 NR: $y=1.4597 x+9.5661(---), \mathrm{r}^{2}=0.7561$, M. caerulea NRS: $y=0.3778 x+8.3071$, $46 \quad \mathrm{r}^{2}=0.2414(-\cdot)$.

47




Figure 3 Leaf characteristics for B. pubescens saplings growing with and without 49 interactions with $C$. vulgaris or $M$. caerulea. Values presented are mean \pm SEM. 50 Data were transformed before analysis (see Table 1).

52 Figure 4 Effect of simulated browsing and competition from different species on the 53 morphology of $B$. pubescens saplings. Values presented are mean \pm SEM. Values 54 were transformed before analysis (see Table 1).
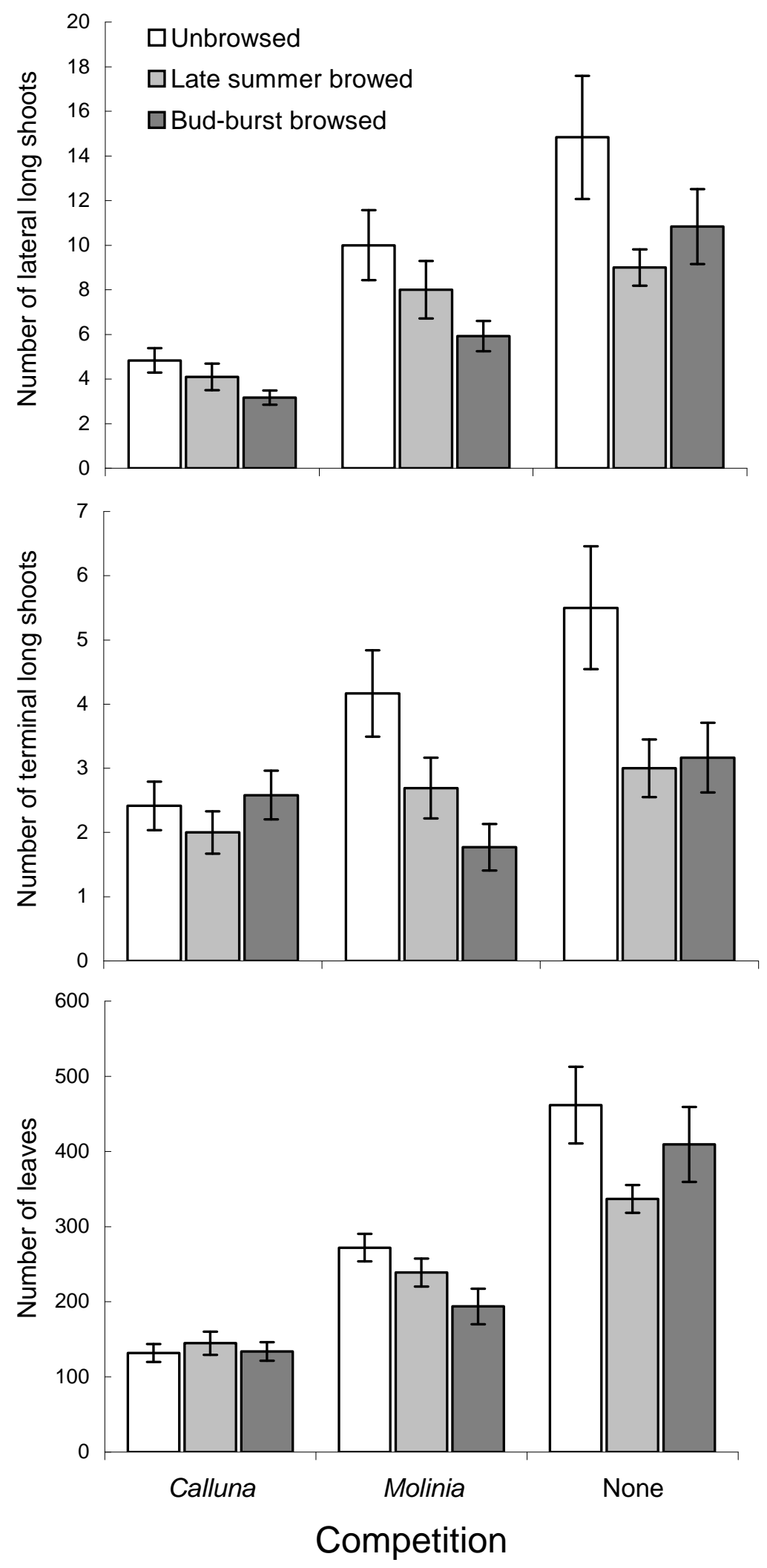